Journal of Business Management and
Economic Research
2019, 3(1): 28-43 DOI: $10.29226 / \mathrm{TR} 1001.2018$.
Journal Homepage: $\mathrm{https://www.jobmer.org}$

\title{
Revealed Comparative Advantage of Textile and Clothing Industry of Bangladesh in the North American Market
}

\section{Mohammad Ali}

Business School, Hohai University, Nanjing, China

College of Business Administration, International University of Business Agriculture and Technology (IUBAT), Bangladesh, Email: mohammadali@iubat.edu

\section{Wang Qun}

Business School, Hohai University, Nanjing, China, Email: wqun@hhu.edu.cn

\section{Md Ekram Hossain}

Business School, Hohai University, Nanjing, China, Email: ekram.iml.du@gmail.com

\begin{abstract}
This paper attempts to investigate the long-term patterns of revealed comparative advantage of the textile and clothing industry of Bangladesh among leading textile and clothing exporting nations in the North American market. A revealed comparative advantage index is employed to evaluate the comparative advantage of the top 5 competitors in the North American market over 38 years period. The analyzed results exhibit tremendous ups and downs of comparative advantage of the selected competitors during 1980-2017 in North American textile and clothing market. In overall analysis during the mentioned period, it shows that Bangladesh revealed the highest comparative advantage over the selected top 5 competitors in the market. Established trade theories remain a useful but limited guide to understanding the dynamics of comparative advantage in the context of the changing global business environment and geopolitical transformation. A deeper understanding of the patterns of change could assist in strategic planning for the concerned stakeholder in the industry.
\end{abstract}

Keywords: International trade, Textile \& Clothing, North American Market, Comparative advantage

\section{Introduction}

Because of falling trade barriers and technological innovation, cheaper and faster transportation, and mass production, trade has grown remarkably, completely transforming the global economy over the last two centuries. Trade transactions include both goods (tangible products that are physically shipped) and services (intangible commodities, such as tourism and financial services) has increased between the countries. In 2017, world trade was \$34 
trillion. That's $\$ 17$ trillion in exports plus $\$ 17$ trillion in imports (AMADEO, 2018). According to the newly released World Trade Statistical Review 2018 by the World Trade Organization (WTO), the current dollar value of world textiles and apparel exports totaled $\$ 296.1 \mathrm{bn}$ and $\$ 454.5$ bn respectively in 2017 , increased by $4.2 \%$ and $2.8 \%$ from a year earlier (Organization, 2018). Asia recorded the highest increase in trade volume with a growth of $8.1 \%$.

Bangladesh is the second largest ready-made garment exporter in the world, has emerged as a key player since 1978. Textiles \& Clothing account for about $85 \%$ of total export of Bangladesh. Out of which $86 \%$ comes from the apparel sector which covers the major products of knit \& woven shirts, blouses, trousers, skirts, shorts, sweaters, sportswear \& many more casual \& fashion items (Hasan, Mia, Rahman, Ullah, \& Ullah, 2016). Bangladesh's main export partners are the European Union, North America and Emerging countries in Asia, South America and Africa (Comtrade, 2018). Textile \& clothes, raw jute, and its derived products, leather, fish and frozen seafood are the main export products of Bangladesh (Comtrade, 2018).

This multi-billion dollar industry of Bangladesh which is playing a major role in economic and infrastructure development of Bangladesh is facing stringent competition from India, Vietnam, Cambodia and China. According to the provisional data of the Export Promotion Bureau (EPB), Bangladesh's apparel export was growing significantly in previous years, but in 2016-2017 FY, the growth rate declined drastically, which has created anxiety over the whole industry (Bangladesh). According to Export Promotion Bureau (EPB) data, Bangladesh's export earnings from the RMG sector stood at $\$ 30.61$ billion, posting $8.76 \%$ growth in the last fiscal year. The figure is $1.51 \%$ higher than the target of $\$ 30.16$ million for FY18.

In FY17, Bangladesh's export earnings registered a $0.2 \%$ growth to $\$ 28.15$ billion, the lowest in the last one and a half decade (Ovi, 2018). The total amount, Knitwear products earned $\$ 15.18$ billion, which is $10.40 \%$ higher than the $\$ 13.76$ in the same period a year ago. Woven products earned $\$ 15.42$ billion, up by $7.18 \%$, compared to $\$ 14.39$ billion a year ago. Meanwhile, Bangladesh's overall export earnings rose about 5.8\% to $\$ 36.66$ billion, which was $\$ 34.65$ billion in the financial year 2017 (Ovi, 2018).

Bangladeshi clothing industry, which mainly depends on foreign buyers, now has to face a new term called competitiveness. Competitiveness is an indicator of the ability to supply goods and services at the location and in the form and at the time sought after by buyers, at prices that are as good as or better than those of potential suppliers, while earning at least the opportunity cost of returns on resources employed Thus, a competitive firm or industry or country have the ability to satisfy the consumers with a product of the right price, right quality, right packaging, etc. (Ilyas, Mukhtar, \& Javed, 2009). Bangladesh needs a strong double-digit growth in export earnings to meet the expenses of development projects. Slower growth in export performance would widen the balance of payments gap, said the economist. With the present growth rate, Bangladesh would not be able to reach the target of $\$ 60$ billion export earnings by 2021, said by Policy Research Institute (PRI) executive director Ahsan H Mansur (Mansur, 2015).

In 2017, Bangladesh exported goods worth US \$ 1.1 billion to Canada, more than 95 percent of which was readymade garment item. The total two-way trade between the two countries was worth the US \$ 1.87 billion in 2017. "Of the total export to Canada from Bangladesh, the majority of products are clothing items, as this North American country has been giving dutyfree trade benefit for all goods to Bangladesh since 2004. Garment shipment to the US, the country's single largest export destination, declined 7.47 percent year-on-year to $\$ 5.2$ billion in 2016-17 largely because of higher duty, longer lead-time, and lower prices (Today, 2017). 
Apparel exporters also blamed the appreciation of the local currency against the American greenback, fewer imports by US retailers and inefficient port operations in Bangladesh are the reasons behind this decline in garment exports. According to the latest data of Bangladesh Export Promotion Bureau, apparel exports to the US during July-Sep 2018 amounted to over USD 1.5 billion, a 3 percent growth from the USD 1.45 billion worth of shipment during the first three months of fiscal 2017-2018 (Today, 2018). Bangladesh relies heavily on the United States, European Union, and Canada for exporting clothing. The comparative advantage of a country in clothing changes as factor endowments, technology, factor prices, and levels of income change. Accordingly, it is necessary to pay attention to changes in the comparative advantages of countries in various categories of clothing. Textile and clothing industry is a labor intensive industry. Each country should end up specializing in the production of the good for which it has a comparative advantage, resulting in an increase in world output, efficiency gains, and potential welfare gains. The country has a comparative advantage in textile production (i.e. a large pool of low-skilled, cheap and docile labor force), this specialization, in turn, would have led to an increase in demand for these low-skilled workers and to a reduction in inequality due to increasing wages.

Therefore this study aims to analyze the comparative advantage of Bangladesh textile and clothing industry export in the North American market compared with its nine other top competitors. In this context, the revealed comparative advantage (RCA) Balassa index (1965) at Harmonized System HS 2-digits levels was used to observe the trade patterns and changes (Balassa, 1977). Balassa developed the 'Revealed Comparative Advantage' (RCA) index concept in order to analyses international trade (Balassa, 1965, 1977). The RCA index identifies the success in exporting of a country compared to the world or a group of countries (Siggel, 2006). This study aims to provide a picture relative position of textile and clothing sector of Bangladesh in the North American markets where few types of research have been conducted before that illustrate the value of this research.

However, the objectives of this research are as following;

i. To explore the overall status of the competitors in the North American Market.

ii. To investigate the challenges faced by Bangladesh's textile and clothing industry in the North American Market.

iii. To uncover the untapped potentiality of Bangladesh's textile and clothing industry in the North American Market.

iv. To confer the sustainable growth of textile and clothing industry of Bangladesh in the North American Market.

\section{Literature Review}

Theoretical foundation and empirical measures of comparative advantage have long been analyzed by trade economists. In particular, Ricardian comparative advantage has long been perceived as a useful pedagogical tool: a country should produce (and export) relatively more in those industries in which it is relatively more productive (Leromain \& Orefice, 2014). Indeed, the Balassa Index of Revealed Comparative Advantage (RCA) as proposed by Bela \& Balassa (1965) has been widely used to approximate countries' sectorial specialization4 but suffers both theoretical foundation and empirical distribution weaknesses (Balassa, 1965). The theoretical foundation of the Balassa Index has long been debated in the literature since it does not really match the original Ricardian idea of comparative advantage (Bowen, 1983; Vollrath, 1991). Ricardian comparative advantage, indeed, is based on the intrinsic (ex-ante) nature of the 
country in being relatively more efficient in the production of a certain good. Unfortunately, Balassa index fails in fitting this idea since it is based on the actual (ex-post) realization of bilateral sector's trade flows, mixing up exporter with the importer and sector-specific factors affecting trade (Leromain \& Orefice, 2014).

However, Imre fertő and lionel j. (2002) Hubbard investigates the competitiveness of Hungarian agriculture in relation to that of the EU where the findings revealed that the pattern of revealed comparative advantage has remained fairly stable in EU market (Fertö \& Hubbard, 2003). Moreover, Studies by (Bhuyan \& Ray, 2006), (Siriwardana \& Yang, 2007), and (Rahman, Khan, Nabi, \& Paul, 2011) they all have made major contribution made valuable contributions in evaluating the comparative advantage of Bangladesh at the bilateral and regional level. Their study was mainly focused on SAARC countries.

Selim Raihan etl. (Mr. Selim Raihan, 1999) used data on the RCA for the selected countries reveal the pattern that as a country becomes more advanced economically, its comparative advantage in clothing changes. In their findings, it's illustrated those countries such as Bangladesh and Sri Lanka which did not have comparative advantages in most of the categories of clothing in 1980, managed to achieve the advantages for most categories by 1996. However, the comparative advantages of these countries are still concentrated on low-value-added categories. China is at a higher level with comparative advantages in all categories of clothing. By contrast, South Korea, a relatively advanced developing country, has lost comparative advantages in most categories of clothing

Moreover, former studies do not facilitate detailed assessment of Bangladesh's comparative advantage in the world market. Moreover, studies that apply Balassa index do not enable to uncover changes in comparative advantage patterns over time. Richardson and Zhang (2001) estimated export patterns variation over time for different sectors and region of USA by using Balassa index. This study found that patterns differ across countries and time for the different level of exports. These differentials are due to geographical immediacy of trading partners and due to per capita income (Richardson \& Zhang, 2001). In a study Bender, Siegfried Li and KuiWai found that export pattern changes with the change in comparative advantage of Asian and Latin American regions (Bender \& Li, 2002). Karakaya, Item Ozgen, and Ferhat have done some research on the effect of trade creation and trade diversion by using Revealed Comparative Advantage and recognized the fact that export structure is different among EU and Turkey (Karakaya \& Ozgen, 2002).

Furthermore, Hanif, Muhammad Nadim Jafri, and Sabina Khurram conducted a study to discuss the role and importance of external finance in the textile sector of Pakistan to increase the competitiveness of export. The finding indicates that access to external finance increases export competitiveness and comparative advantage (Hanif \& Jafri, 2008). Akhtar, Naseem

Zakir, Nadia and Ghani, Ejaz used RCA to measure the performance of the footwear industry of Pakistan and further compared the RCA of footwear industry of Pakistan with the footwear industries of India and China. Covering the period of 1996 to 2006 this study revealed that at HS 2-digit level Pakistan's footwear industry faced a shift in comparative advantage. Though India and China have a comparative advantage since 1990 it decreased over time (Akhtar, Zakir, \& Ghani, 2008). Ruma Bhattacharyya investigated comparative advantage and competitiveness for horticultural products of India and compared the advantage in these commodities with major rivals of these commodities such as North American, Asian and EU 
markets and concluded that India had a comparative advantage in fruits and vegetable sectors (Bhattacharyya, 2011).

Additionally, Shahab, Sadaf Mahmood, and Muhammad Tariq estimated revealed the comparative advantage of leather industry and various leather products of Pakistan, China, India, and Iran, by using Balassa index (1965) for the period of 2002 to 2009. This study found an increasing trend of comparative advantage movement of the leather industry of Pakistan. The study indicates that Pakistan has a significant potential for growth in this sector (Shahab \& Mahmood, 2012).

Furthermore, Lalit Mohan Kathuria calculated RCA of export performance of the clothing sector of India and Bangladesh. This study used the Harmonized System (HS up to 4-digit level) to analyze competitive advantage of various clothing products for the period of 1995 to 2003 for both countries. This study revealed that comparative advantage in clothing products of India increased from 23 products to 25 products and comparative advantage of the same products of Bangladesh increased from 21 to products to 29 products in this period (Mohan Kathuria, 2013).

Research has been done by (Siriwardana \& Yang, 2007), and (Bhuyan \& Ray, 2006) to measure comparative advantage of Bangladesh at regional as well as the bilateral level to fill-up the study gap because the previous study did not make a detailed analysis of comparative advantage.

N Ratkorm used RCA to compare the competitiveness of trade between Thailand and Australia during Thai-Australia Free Trade Agreement period and summarized that Thailand had comparative advantage in five business sectors over Australia and those are parts and accessories vehicles, cultured or natural precious stones, articles of iron and steel, plastic, and air-conditioning machines (Ratkorm, 2008).

Serin, Vildan Civan, and Abdulkadir analyzed competitiveness in the export of Turkish to EU and mentioned that Turkey has a comparative advantage in almost all the traded sector to EU (Serin \& Civan, 2008). In a study of comparative advantage of bilateral trade between China and Australia, Yu Sheng and Ligang Song found that bilateral trade is advantageous for both in the main commodities like agricultural products, petroleum products, textile, and clothing products (Sheng \& Song, 2008).

However, few these types of research have been conducted on the comparative advantage or competitiveness analysis of Bangladesh's textile and clothing industry in the North American Market that motivated this research to be conducted.

\section{Research Methods and Data Sources}

This study analyzed the revealed comparative advantage (RCA) Balassa index for textile and clothing sector of the top exporters respectively Bangladesh, Cambodia, China, India, and Vietnam in North American market (United States of America and Canada). For this purpose annual export data has been taken from the website of World Trade Organization (WTO) and World Integrated Trade Solution (WITS) from 1980 to 2017. The mentioned 37 years data of textile and clothing industry trade has been analyzed by using Microsoft Excel program (Organization, 2018; WITS, 2018).

Balassa explored the possibility of relying on various theoretical explanations of international trade to determine patterns of comparative advantage (Balassa, 1965, 1977, 1979). In this research, we used the Balassa index to explore the comparative advantage of the textile and 
clothing industry of Bangladesh with other top nine competitors of this industry in North American market.

The Balassa index is explained as following; $R C A($ BalassaIndex $)=X_{i j} / X_{i n} \div X_{w j} /{ }_{X w n}$ Where $\mathrm{X} i \mathrm{j}$ is the export of country $\mathrm{i}$, for, $\mathrm{j}$ commodity and $\mathrm{n}$ is a set of all exported commodities of country $i$, while Xwj represents the export of world for same commodity $j$ and Xwn is a world export of all $n$ commodities. According to the results of this index if RCA $>1$ then a country has comparative advantage, if $\mathrm{RCA}<1$ then a country has comparative disadvantage in that commodity or industry.

Based on Balassa index we developed the following equation from 1-10 to analyze the RCA of the mentioned top 10 competitors in North American market for their export of goods in Textile and Clothing industry.

$R C A_{B D}=X_{B D T C} / X_{B D T E x} \div X_{\text {WTC }} / X_{\text {WTEX }}$

Here, RCAвр indicates the revealed comparative advantage of Bangladesh, $\mathrm{X}_{\mathrm{BD}} \mathrm{C}$ demonstrates

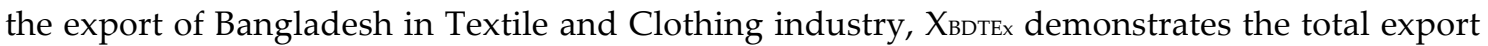
of Bangladesh in that concern year, $X_{\text {WTC }}$ indicates the global export value in textile and clothing industry and $\mathrm{XW}_{\mathrm{TEx}}$ indicates the total global export in all products on that concern year.

$R C A_{K H}=X_{K H T C} / X_{K H T E x} \div X_{W T C} / X_{W T E x}$

Here, RCAкн indicates the revealed comparative advantage of Cambodia, $\mathrm{X}_{\text {кнтс demonstrates }}$

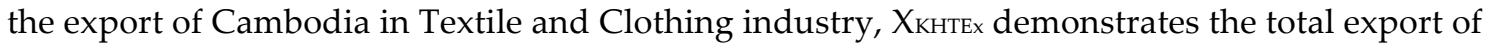
Cambodia in that concern year, $X_{\text {wтc }}$ indicates the global export value in textile and clothing industry and $\mathrm{XW}_{\text {TEx }}$ indicates the total global export in all products on that concern year.

$$
R C A_{C N}=X_{C N T C} / X_{C N T E x} \div X_{W T C} / X_{W T E x}
$$

Here, RCACN indicates the revealed comparative advantage of China, $\mathrm{X}_{\mathrm{KHTC}}$ demonstrates the

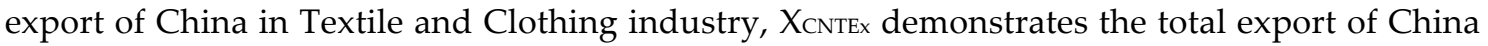
in that concern year, $X_{\text {WTC }}$ indicates the global export value in textile and clothing industry and $\mathrm{XW}$ тех indicates the total global export in all products on that concern year.

$$
R C A_{I N}=X_{I N T C} / X_{I N T E x} \div X_{W T C} / X_{W T E x}
$$

Here, RCAIN indicates the revealed comparative advantage of India, $X_{\text {INTC demonstrates the }}$ export of India in Textile and Clothing industry, $X_{\text {INTEx }}$ demonstrates the total export of India in that concern year, $X_{\text {wT }}$ indicates the global export value in textile and clothing industry and $\mathrm{XW}$ TEx indicates the total global export in all products on that concern year.

$$
R C A_{V N}=X_{V N T C} / X_{V N T E x} \div X_{W T C} / X_{W T E x}
$$

Here, RCAvn indicates the revealed comparative advantage of Vietnam, $X_{\text {VNTC }}$ demonstrates the export of Vietnam in Textile and Clothing industry, $\mathrm{X}_{\mathrm{VNTEx}}$ demonstrates the total export of Vietnam in that concern year, $X_{\text {штc }}$ indicates the global export value in textile and clothing industry and $\mathrm{XW}$ TEx indicates the total global export in all products on that concern year. 
We used the Harmonized System (HS) HS 1988/92 and SITC Revision 2 of international nomenclature for the classification of products in 2 digits levels to analyze the comparative advantage for the whole industry (UNSTATS, 2018; W. I. T. S. WITS, 2018).

Table 1: Textile and Clothing Industry Products according to Harmonized System (HS)

\begin{tabular}{cl}
\hline Harmonized System (HS) Product Code & \multicolumn{1}{c}{ Product Description } \\
\hline HS 50 & Silk. \\
HS 51 & Wool, fine/coarse animal hair, horsehair yarn \\
HS 52 & Cotton. \\
HS 53 & Other vegetable textile fibers; paper yarn \& w \\
HS 54 & Man-made filaments. \\
HS 55 & Man-made staple fibers. \\
HS 56 & Wadding felt \& nonwoven; yarns; twine, cordage \\
HS 57 & Carpets and other textile floor coverings. \\
HS 58 & Special woven fab; tufted tex fab; lace; tapes \\
HS 59 & Impregnated, coated, cover/laminated textile f \\
HS 60 & Knitted or crocheted fabrics. \\
HS 61 & Art of apparel \& clothing access, knitted \\
HS 62 & Art of apparel \& clothing access, not knitted/ \\
HS 63 & Other made up textile articles; sets; worn \\
\hline
\end{tabular}

Source: World Integrated Trade Solutions, accessed in December 2018; (W. I. T. S. WITS, 2018)

Table 2: Textile and Clothing Industry Products according to Standard International Trade Classification (SITC) Revision-2

\begin{tabular}{cl}
\hline SITC Revision 2 Product Code & \multicolumn{1}{c}{ Product Description } \\
\hline SITC 26 & Textile fibers (except wool tops) and their wastes \\
SITC 65 & Textile yarn, fabrics, made-upart., related products \\
SITC 26 & Textile fibers (except wool tops) and their wastes \\
SITC 65 & Textile yarn, fabrics, made-upart., related products \\
SITC 84 & Articles of apparel and clothing accessories \\
\hline
\end{tabular}

Source: UN Trade Statistics, accessed in December 2018; (Statistics, 2018)

\section{Results and Discussion}

The analyzed results (fig. 1 and table. 3) exhibit tremendous ups and downs of comparative advantage during 1980-2017 for the selected competitors in North American textile and clothing market. During these four decades, the pattern of trade and competitiveness of textile and clothing industry of the mentioned countries faced significant transformation. 


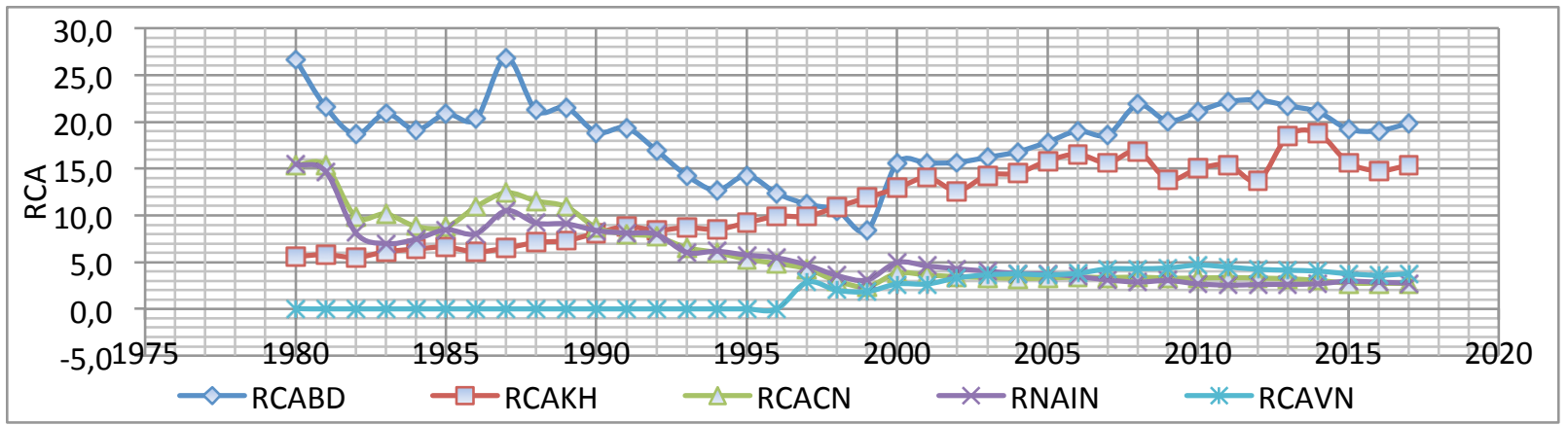

Figure 1: Analyzed RCA value of the selected countries during 1980-2017

Table 3: Analyzed RCA of the Top 5 Competitors

\begin{tabular}{lcccccccc}
\hline & $1980-85$ & $1986-90$ & $1991-95$ & $1996-00$ & $2001-05$ & $2006-10$ & $2011-15$ & $2016-17$ \\
\hline RCAвр & 21.3 & 21.8 & 15.5 & 11.6 & 16.4 & 20.1 & 21.3 & 19.5 \\
RCAкн & 0.5 & 0.7 & 0.8 & 2.6 & 14.3 & 15.6 & 16.4 & 15.1 \\
RCAcn & 11.4 & 10.9 & 6.7 & 3.7 & 3.4 & 3.3 & 3.1 & 2.7 \\
RCA & 10.2 & 9.0 & 6.8 & 4.4 & 4.1 & 3.0 & 2.7 & 2.8 \\
RCAvn & 1.3 & 1.1 & 1.4 & 1.9 & 3.4 & 4.3 & 4.1 & 3.7 \\
\hline
\end{tabular}

In 80 decade Bangladesh was the remained the top one having average RCA value 21.8 while China and India positioned the second and third consequently having average RCA value 11.4 and 9.4 while Vietnam didn't possess any comparative advantage during this period for its export of textile and clothing industry goods (fig. $2 \& 3$ ).

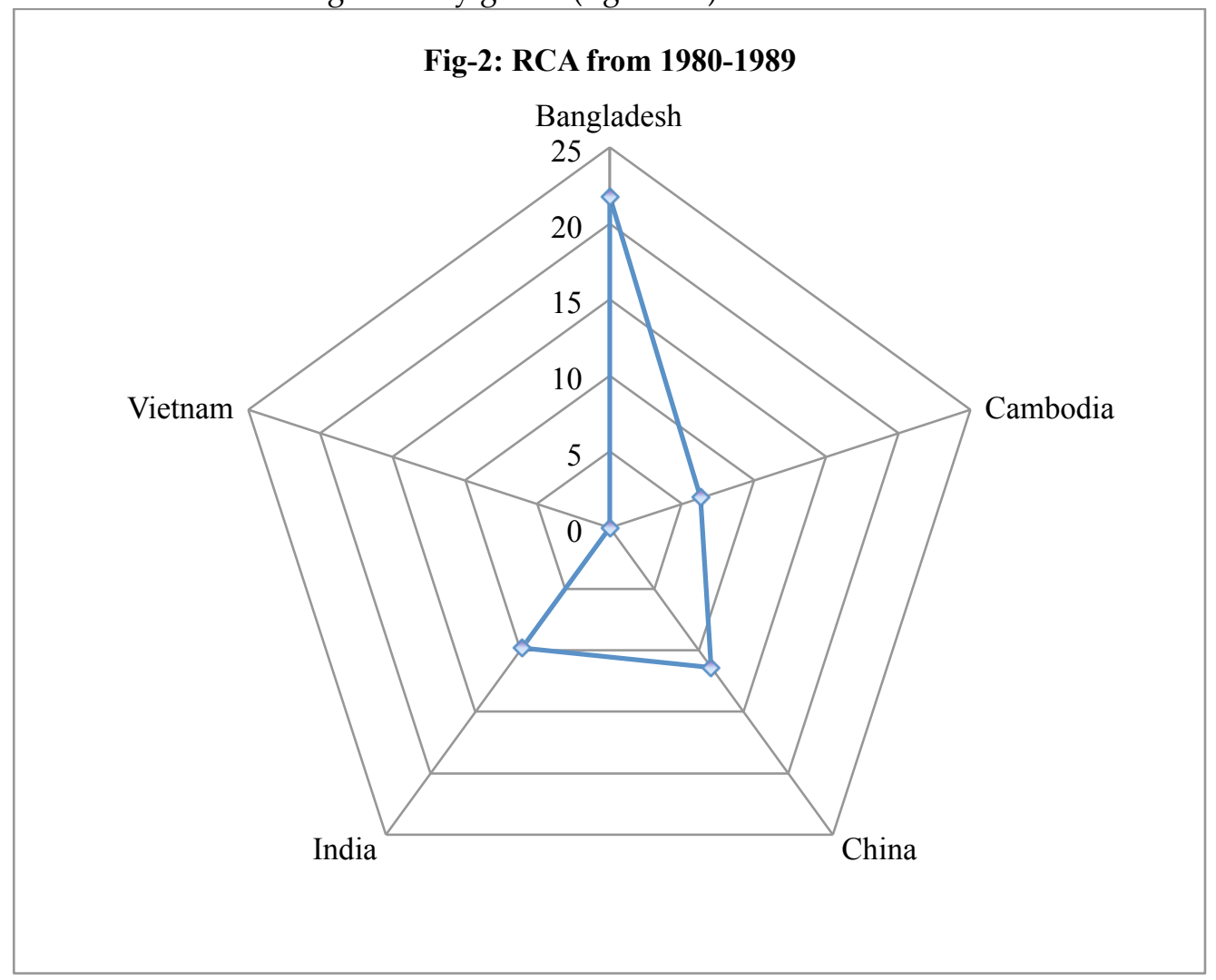




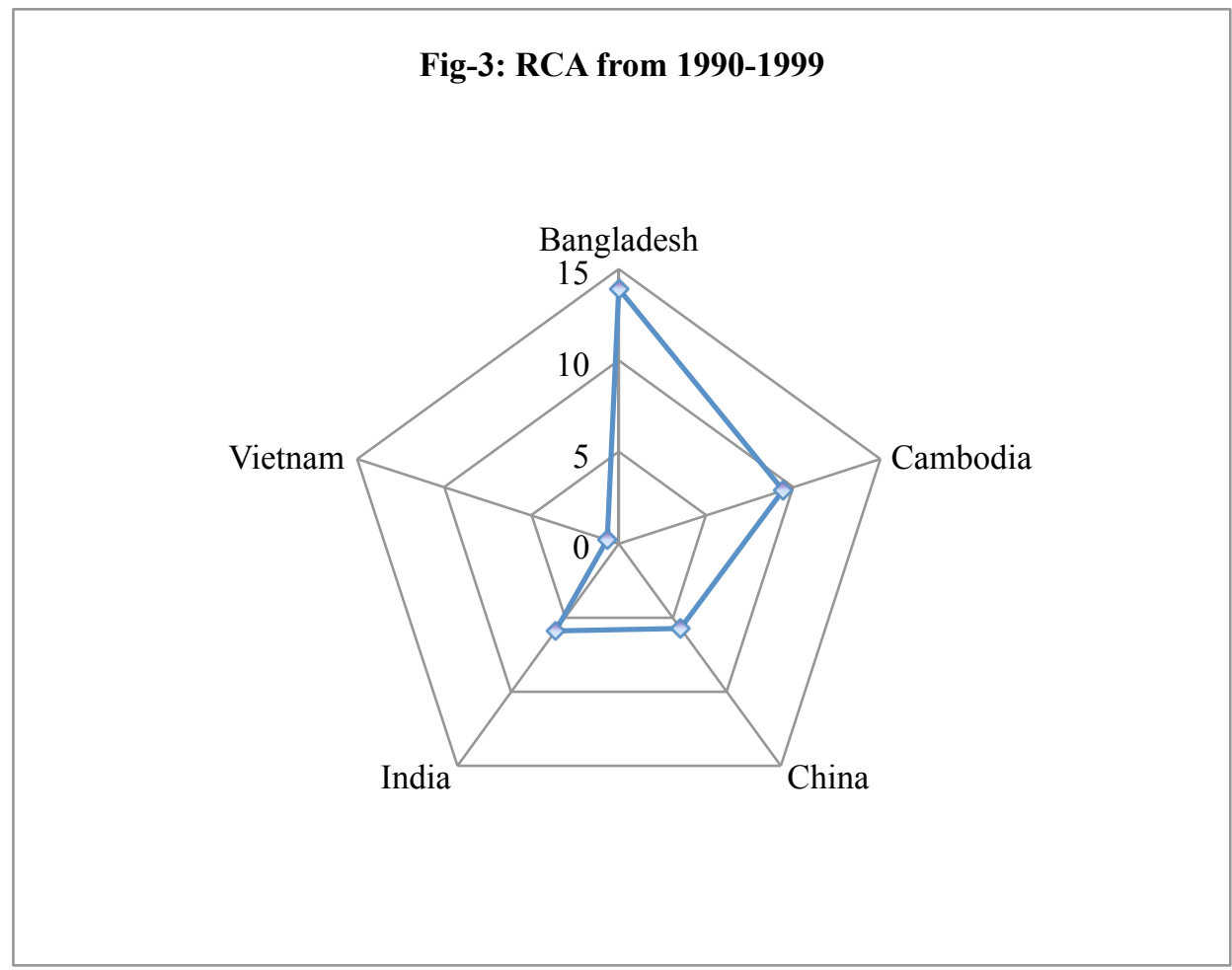

However, the RCA value of the selected countries dropped significantly during the 90 decade especially at the end of the 90 decade it's because of the global financial recession at that period. In this decade Bangladesh kept its top position having average RCA value 13.9 while India lost its $2^{\text {nd }}$ position dropped to 5.9 in the third position. On the contrary Cambodia came to the second competitor's position having RCA value 9.4 in this decade. China also lost its $3^{\text {rd }}$ position to $4^{\text {th }}$ having average RCA value 5.7 and Vietnam kept its last position increasing a bit in its average RCA 0.7 during this period.

Fig-4: RCA from 2000-2009

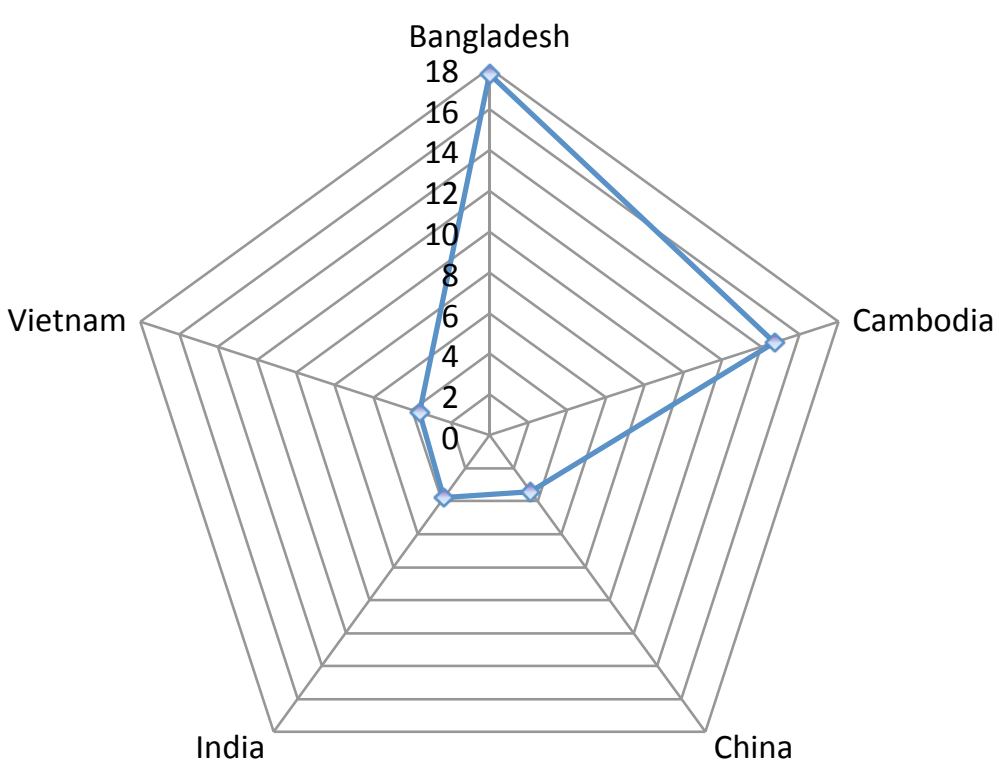




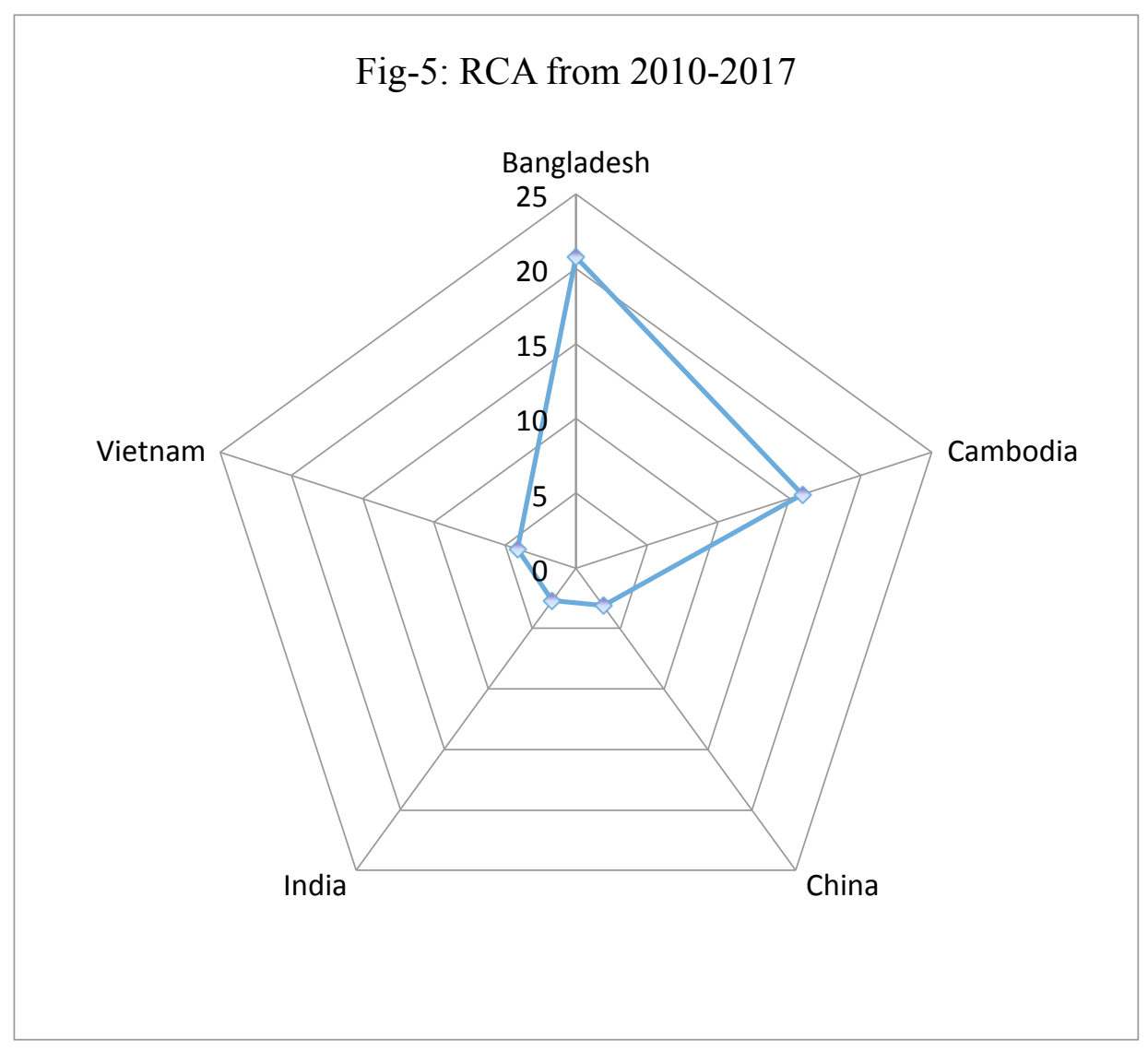

In the decade of 2000, the countries gradually gained their comparative advantage since the countries had been overcoming the global economic recession. In this period there also happened significant transformation of competition in textile and clothing in the global market. During this period Bangladesh kept its top position having average RCA 17.7 while Cambodia emerged as the $2^{\text {nd }}$ positioned country for its revealed comparative advantage having the value of 14.7 and India kept its $3^{\text {rd }}$ position. Another change took place during this period that's Vietnam achieved the $4^{\text {th }}$ position overcoming China (fig. $4 \& 5$ ).

Furthermore, in the 2010 th decade, some of the competitors gained higher comparative advantage than the previous decade and some other's comparative advantage decreased during this period. Consequently, Bangladesh kept its top position having the revealed comparative advantage average value 20.8 while Cambodia kept its $2^{\text {nd }}$ position having average $R C A$ value 15.9 in this decade. Another indicative transformation took place during this decade that revealed Vietnam as the $3^{\text {rd }}$ top country in terms of comparative advantage in its textile and apparel industry export. While China and India kept the $4^{\text {th }}$ and $5^{\text {th }}$ position respectively during this period.

However, after European Union, North American market is the second largest (20\%) market for Bangladesh's textile and apparel export (MIT, 2018). Bangladesh's export volume in textile and clothing to North America accounted around 6 billion US\$ in 2017 (appendix 4) that's indicate the importance of this market for Bangladesh's export as well as for the economy. It's very important for the industry to keep its growth up as well as stable in the North American market. In 2017 total import of North American market in the textile and clothing accounted 126 Billion US\$ (appendix 2) where the analyzed 5 countries are the top competitors in this market. In this research, although China revealed lower comparative advantage than Bangladesh, it 
showed the largest absolute difference between potential and actual exports in value terms in the North American Market of textile and clothing.

According to the analysis of the ITC's export potential map, China is the biggest player in North America having $59.9 \%$ share of textile and clothing import of the region. Amounting 44.3 billion US\$ export to North America, China revealed 73.6 billion US\$ future export potential to this market. Having \$29.5 billion untapped potential remaining for China in North American Market which is the biggest amount for this top competitor in this market (ITC, 2018). Vietnam revealed itself as the second largest exporter to the North American market having US\$12.1 Billion and it stated $\$ 608.1$ million untapped export potential in this market. India revealed $\$ 10.4$ billion export potential where $\$ 3.5$ billion remaining untapped potential having their current export of $\$ 7.6$ billion. Bangladesh listed the $3^{\text {rd }}$ top exporter in this market having current export of $\$ 6.7$ billion and revealing $\$ 2.9$ billion of untapped export potential in North American Market according to the export potential map of ITC. Furthermore, Cambodia also revealed $\$ 3.8$ billion export potential having $\$ 946.2$ million untapped export potential in the North American Market.

However, in this research, the attempt was to explore the overall status of the competitors in North American Market as well as to uncover the untapped potentiality of Bangladesh's textile and clothing industry in North American Market. The concern authorities and the industry stakeholders should take proper steps to confer a sustainable growth of textile and clothing industry export of Bangladesh in the North American Market overcoming all the challenges grabbing the .untapped potential of Bangladesh's industry over the other competitors in this market.

\section{Conclusions and Recommendations}

Textile and clothing sector has emerged as the main industry within a few decades that appeared to be crucial for the economy as a source of export earnings and employment generation. Since higher income nations generally remain stronger in more capital-intensive sectors, while lower-income countries have emerged to dominate labor-intensive sectors. Nevertheless, cheap labor, preferential access, low investment, and energy cost will no more considered to be the basis of competitive advantage for the industry at this era of multifunctional competition in the global market including the North American market since Bangladesh's graduation from the LDC's country status.

By embracing a long-term time frame, a broad array of nations and a vertical complex industry perspective to identify shifting patterns of comparative advantage, this paper highlights the key dynamics of revealed comparative advantage of Bangladesh with its major competitors in the North American market. The empirical findings from this paper stated that Bangladesh has higher comparative advantage over the other major competing countries in the North American market. This result also revealed that the some emerging competitors e.g. Cambodia and Vietnam could grab larger market share of textile and clothing in the North American market if Bangladesh fails to keep or upraise its comparative advantage factors e.g. the extent of specialization and diversification, technological development, natural resource endowment, international political diplomacy, destination countries' trade facilitation policies (GSP) and the effects of economic integration and so on in the coming years.

However, further research could be conducted on the product specialization and diversification which could reveal more insights of the industry for its export diversification in the North American Market. Moreover, inclusion of a more complex array of variables is necessary to obtain a fuller understanding of comparative advantage among the competitors. 


\section{REFRENCES}

Akhtar, N., Zakir, N., \& Ghani, E. (2008). Changing revealed comparative advantage: A case study of footwear industry of Pakistan. The Pakistan Development Review, 695-709.

AMADEO, K. (2018). International Trade, Its Pros, Cons, and Effect on the Economy. from https://www.thebalance.com/international-trade-pros-cons-effect-on-economy-3305579

Balassa, B. (1965). Trade liberalization and "revealed" comparative advantage 1. The Manchester School, 33(2), 99-123.

Balassa, B. (1977). 'Revealed comparative advantage revisited: An analysis of relative export shares of the industrial countries, 1953-1971. The Manchester School, 45(4), 327-344.

Balassa, B. (1979). The changing pattern of comparative advantage in manufactured goods. The Review of Economics and statistics, 259-266.

Bangladesh, E. P. B. E. o. Statistic Data-2016-2017. from http://www.epb.gov.bd/site/files/ 51916ae6-a9a3-462e-a6bd-9ef074d835af/Statistic-Data-2016-2017

Bender, S., \& Li, K.-W. (2002). The changing trade and revealed comparative advantages of Asian and Latin American manufacture exports.

Bhattacharyya, R. (2011). Revealed comparative advantage and competitiveness: a case study for India in horticultural products. Paper presented at the International Conference On Applied Economics-ICOAE.

Bhuyan, A., \& Ray, S. (2006). Feasibility study on bilateral FTA within SAARC region. ACE Report(2).

Bowen, H. P. (1983). On the theoretical interpretation of indices of trade intensity and revealed comparative advantage. Weltwirtschaftliches Archiv, 119(3), 464-472.

Comtrade, U. (2018). UN Comtrade Database. from https://comtrade.un.org/

Fertö, I., \& Hubbard, L. J. (2003). Revealed comparative advantage and competitiveness in Hungarian agri-food sectors. World Economy, 26(2), 247-259.

Hanif, M. N., \& Jafri, S. K. (2008). Financial development and textile sector competitiveness: A case study of Pakistan. South Asia Economic Journal, 9(1), 141-158.

Hasan, K. F., Mia, M. S., Rahman, M. M., Ullah, A. A., \& Ullah, M. S. (2016). Role of textile and clothing industries in the growth and development of trade \& business strategies of Bangladesh in the global economy. International Journal of Textile Science, 5(3), 39-48.

Ilyas, M., Mukhtar, T., \& Javed, M. T. (2009). Competitiveness among Asian exporters in the world rice market. The Pakistan Development Review, 783-794.

ITC. (2018). Export Potential of Bangladesh Textile and Clothing. Retrieved December, 2018, from http://exportpotential.intracen.org/\#/markets/geo-map?fromMarker=i\&exporter $=50 \&$ whatMarker $=1$ s\&what $=13 \&$ toMarker $=j$

Karakaya, E., \& Ozgen, F. (2002). Economic Feasibility of Turkey's Economic Integration with the EU: Perspectives from Trade Creation and Trade Diversion.

Leromain, E., \& Orefice, G. (2014). New revealed comparative advantage index: dataset and empirical distribution. International Economics, 139, 48-70.

Lu, S. (2018). WTO Reports World Textile and Apparel Trade in 2017 (Vol. August 16, 2018). USA: Department of Fashion \& Apparel Studies, University of Delaware.

Mansur, A. H. (2015). Financial Market Developments and Challenges in Bangladesh. Policy Research Institute of Bangladesh. Prepared as a Background paper for the Seventh Five Year Plan. Available: http://www. plancomm. gov. bd/wp-content/uploads/2015/02/9_FinancialMarket-Developments-and-Challenges-in-Bangladesh. pdf.

MIT, A. (2018). The Observatory of Economic Complexity. Retrieved December, 2018, from https://atlas.media.mit.edu/en/visualize/tree_map/hs92/export/bgd/all/show/2016/ 
Mohan Kathuria, L. (2013). Analyzing competitiveness of clothing export sector of India and Bangladesh: Dynamic revealed comparative advantage approach. Competitiveness Review: An International Business Journal, 23(2), 131-157.

Mr. Selim Raihan, R. F., CPD (1999). The Textile and Clothing Industry of Bangladesh in a Changing World Economy (C. D. C. Ms Ayesha Banu, CPD Ed.): Centre for Policy Dialogue.

Organization, W.-W. T. (2018). World Trade Statistical Review 2018. from www.wto.org

Ovi, I. H. (2018). RMG exports saw $8.76 \%$ growth last fiscal year, DhakaTribune. Retrieved from https://www.dhakatribune.com/business/2018/07/05/rmg-exports-saw-8-76-growth-lastfiscal-year

Rahman, M., Khan, T. I., Nabi, A., \& Paul, T. K. (2011). Bangladesh's export opportunities in the Indian market: Addressing barriers and strategies for future. South Asia Economic Journal, 12(1), 117-141.

Ratkorm, N. (2008). Comparative Advantage of Thailand's export product in Australia During Free Trade Agreement Thailand-Australia.

Richardson, J. D., \& Zhang, C. (2001). Revealing comparative advantage: chaotic or coherent patterns across time and sector and US trading partner? Topics in Empirical International Economics: A Festschrift in Honor of Robert E. Lipsey (pp. 195-232): University of Chicago Press.

Serin, V., \& Civan, A. (2008). Revealed comparative advantage and competitiveness: a case study for Turkey towards the EU. Journal of Economic and Social Research, 10(2), 25-41.

Shahab, S., \& Mahmood, M. T. (2012). Comparative advantage of leather industry in Pakistan with selected Asian economies. International Journal of Economics and Financial Issues, 3(1), 133-139.

Sheng, Y., \& Song, L. (2008). Comparative Advantage and Australia-China Bilateral Trade. Economic Papers: A journal of applied economics and policy, 27(1), 41-56.

Siggel, E. (2006). International competitiveness and comparative advantage: a survey and a proposal for measurement. Journal of Industry, Competition and Trade, 6(2), 137-159.

Siriwardana, M., \& Yang, J. (2007). Effects of proposed free trade agreement between India and Bangladesh. South Asia Economic Journal, 8(1), 21-38.

Statistics, U. T. (2018). SITC Classification Commodity Code and Commodity description. Retrieved 2018, from United Nations https://unstats.un.org/unsd/tradekb/ Knowledgebase/50262/Search-SITC-code-description

Today, T. (2017). Why Bangladesh apparel exports to US is declining. from https://www.textiletoday.com.bd/bangladesh-apparel-exports-us-declining/

Today, T. (2018). Bangladesh's apparel export to US pushes up in Jul-Sep 2018. from https://www.textiletoday.com.bd/bangladeshs-apparel-export-us-pushes-up-jul-sep2018/

UNSTATS. (2018). Harmonized Commodity Description and Coding Systems (HS). Retrieved 2018, from

UNSTATS https://unstats.un.org/unsd/tradekb/Knowledgebase/50018/Harmonized-CommodityDescription-and-Coding-Systems-HS

Vollrath, T. L. (1991). A theoretical evaluation of alternative trade intensity measures of revealed comparative advantage. Weltwirtschaftliches Archiv, 127(2), 265-280.

WITS. (2018). North America Textiles and Clothing Imports By Country and Region 2016. Retrieved from:

https://wits.worldbank.org/CountryProfile/en/Country/NAC/Year/2016/TradeFlow/Exp ort/Partner/all/Product/50-63_TextCloth

WITS, W. I. T. S. (2018). Harmonized System 1988/92. Retrieved 2018, from World Bank https://wits.worldbank.org/product-metadata.aspx 


\section{Appendix:}

Appendix 1: Top 10 Exporters in Global Markets of Textile and Clothing, (Value in Billion USD)

\begin{tabular}{lccccccccc}
\hline Exporters & Value & \multicolumn{4}{c}{ Share in world exports (\%) } & \multicolumn{3}{c}{ Annual percentage change (\%) } \\
\hline & 2017 & 2000 & 2005 & 2010 & 2017 & $2010-17$ & 2015 & 2016 & 2017 \\
China & 290 & 28.6 & 46.9 & 67.2 & 72 & 8 & -8 & -13 & 5 \\
European Union (28) & 199 & 65.4 & 65.9 & 55.4 & 52 & 4 & -26 & 5 & 17 \\
Extra-EU (28) & 52 & 16.3 & 16.6 & 14.3 & 13.9 & 5 & -28 & 0 & 17 \\
India & 35 & 6.6 & 7.2 & 8.3 & 9.9 & 11 & -3 & -8 & 8 \\
Bangladesh & 34 & 2.6 & 2.5 & 4.2 & 6.5 & 10 & 8 & 8 & 2 \\
Vietnam & 34 & 1.1 & 2.1 & 4.1 & 8.4 & 27 & 15 & 24 & 27 \\
Turkey & 26 & 5.7 & 7.8 & 7.2 & 7.2 & 6 & -21 & 0 & 5 \\
USA & 20 & 11.5 & 7.9 & 6.1 & 5.8 & 5 & -3 & -15 & 6 \\
Korea Republic & 10 & 8.2 & 5.1 & 4.4 & 3.3 & -2 & -11 & -6 & -2 \\
Taiwan & 9 & 7.7 & 4.8 & 3.9 & 3.1 & -1 & -6 & -7 & 3 \\
Pakistan & 8 & 2.9 & 3.5 & 3.1 & 2.7 & 0 & -9 & -7 & 4 \\
Indonesia & 8 & 2.4 & 1.8 & 1.9 & 1.8 & 3 & -1 & -2 & 10 \\
Cambodia & 7 & 0.5 & 0.8 & 0.9 & 1.6 & 13 & 11 & 12 & 8 \\
\hline
\end{tabular}

Source: Dr. Sheng Lu, University of Delaware, (Lu, 2018); compiled by the Authors in 2018

Appendix 2: Top 10 Importers of Textile and Clothing in Global Markets (Value in Billion USD)

\begin{tabular}{lccccccccc}
\hline Importers & Value & \multicolumn{3}{c}{ Share in world imports (\%) } & \multicolumn{3}{c}{ Annual percentage change (\%) } \\
\hline & 2017 & 2000 & 2005 & 2010 & 2017 & $2010-17$ & 2015 & 2016 & 2017 \\
European Union (28) & 261 & 76.3 & 80.9 & 73.1 & 61.8 & 2 & -21 & 3 & 0 \\
Extra-EU (28) & 130 & 29.5 & 33.4 & 34.1 & 30 & 4 & -17 & 1 & 8 \\
USA & 116 & 42.8 & 39.2 & 30.9 & 27.1 & 4 & 9 & -9 & -5 \\
China & 43 & 8.4 & 7.8 & 7.3 & 7 & 16 & 1 & -14 & 15 \\
Japan & 36 & 12.7 & 10.8 & 10 & 8.4 & 3 & -16 & -2 & 4 \\
Vietnam & 14 & 0.8 & 1.6 & 2.6 & 4.3 & 10 & 6 & 1 & 5 \\
Canada & 10 & 1.8 & 2.1 & 2.2 & 2.1 & 3 & -2 & -3 & 6 \\
Korea Republic & 9 & 0.6 & 1 & 1.2 & 1.9 & 11 & 1 & 1 & 8 \\
Bangladesh & 9 & 0.8 & 1.1 & 1.7 & 3 & 11 & 21 & 7 & 7 \\
Turkey & 7 & 1.3 & 2.1 & 2.5 & 2.2 & 1 & -12 & -2 & 12 \\
Australia & 7 & 1.6 & 1.6 & 1.4 & 1.4 & 3 & -8 & 6 & 13 \\
Russian Federation & 7 & 0.1 & 0.3 & 2 & 1.5 & -1 & -34 & 3 & 26 \\
Mexico & 6 & 3.6 & 2.8 & 1.9 & 2 & 3 & 2 & -4 & 1 \\
Indonesia & 6 & 0.8 & 0.4 & 1.6 & 1.9 & 5 & -2 & 3 & 4 \\
\hline
\end{tabular}

Source: Dr. Sheng Lu, University of Delaware, (Lu, 2018); compiled by the Authors in 2018 
Appendix 3: Share of the top 10 Import Partners of North America in Textile \& Clothing (Share \%)

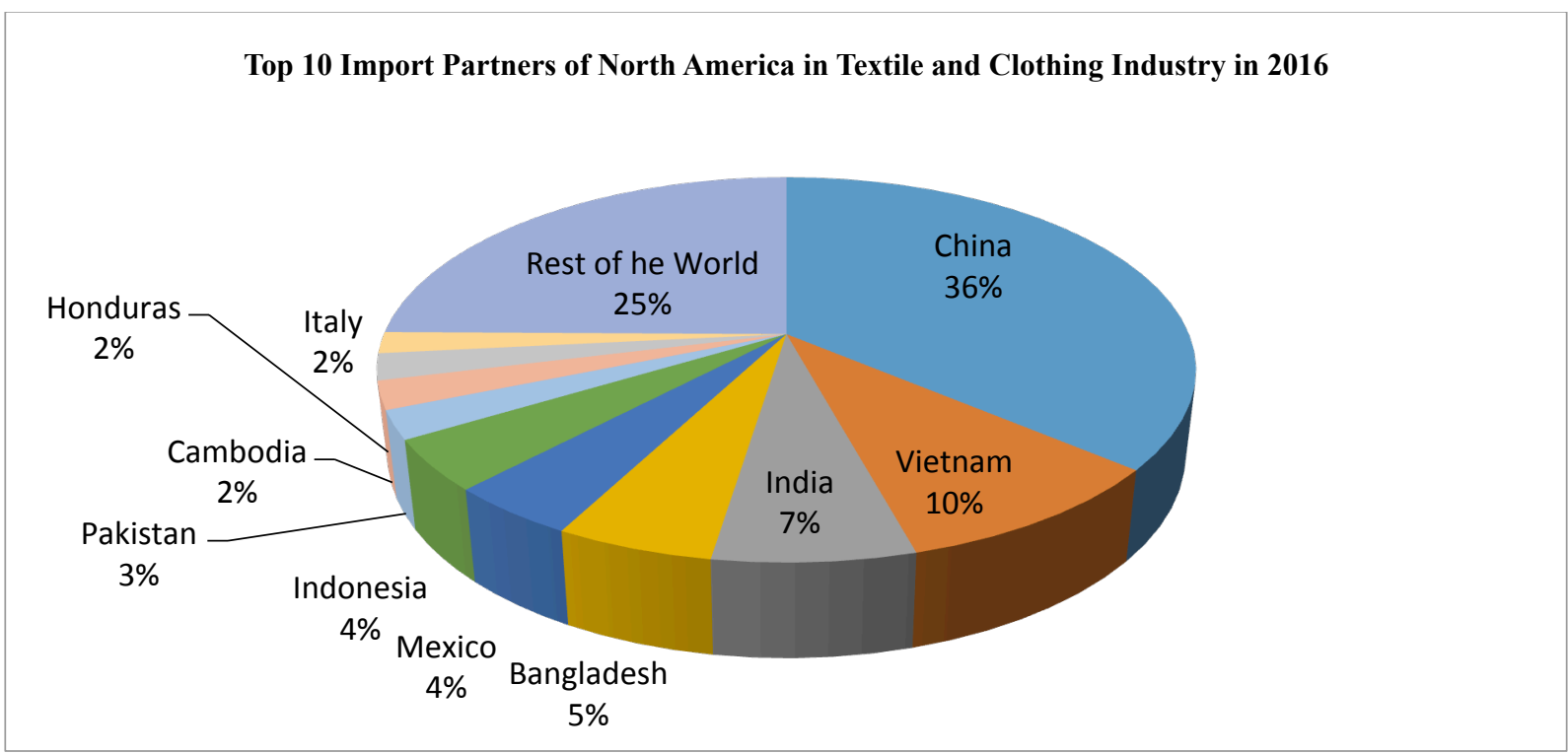

Source: Word Integrated Trade Solutions, (WITS, 2018); Compiled by the Authors in 2018

Appendix 4: Top 10 Import Partners of North America in Textile and Clothing in 2016 (Value Billion USD)

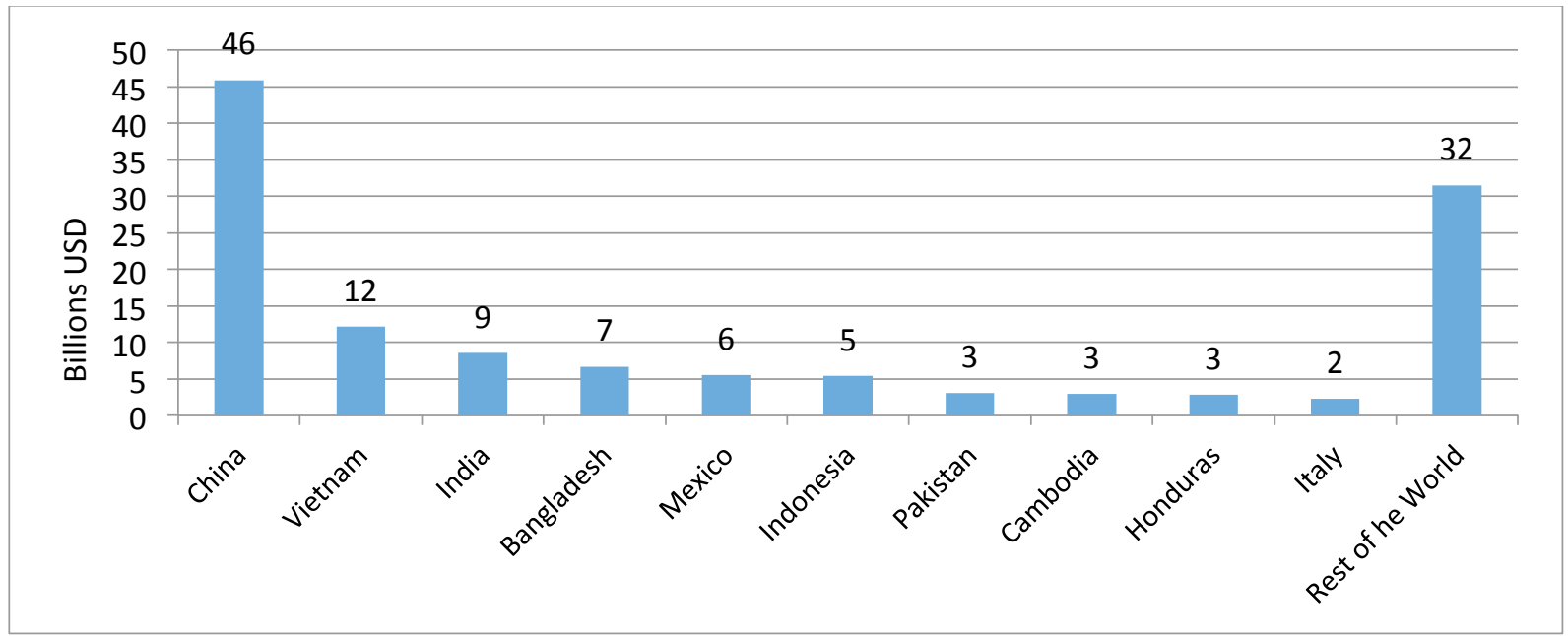

Source: Word Integrated Trade Solutions, (WITS, 2018); Compiled by the Authors in 
Journal of Business Management and Economic Research, vol.3, issue.1, pp.28-43

Appendix 5: Export Potential of Bangladesh's Textile and Clothing Industry in North American Market

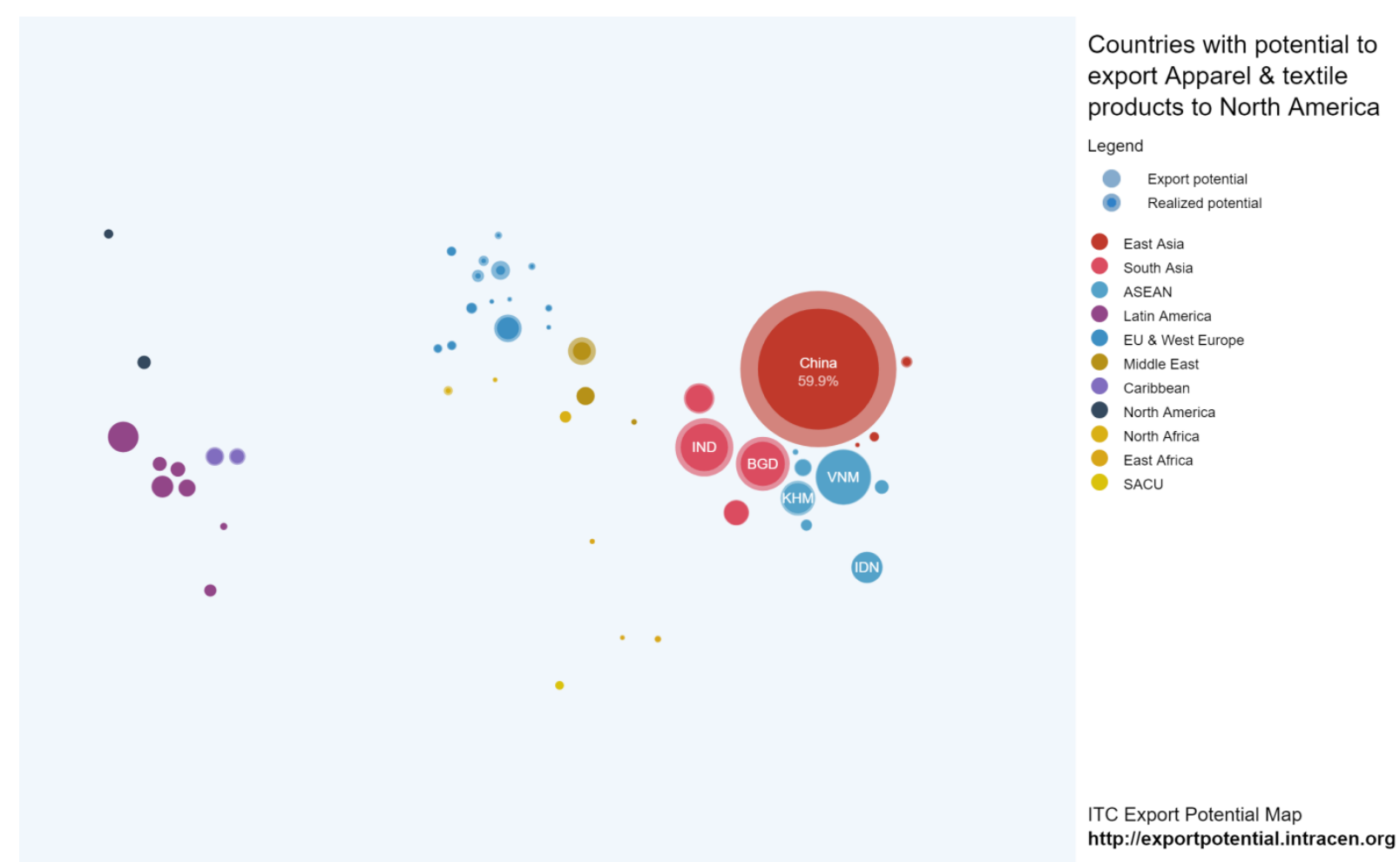

Source: Export Potential Map of ITC; Accessed in 2018; (ITC, 2018) 